\title{
Destination Resilience and Innovation for Advanced Sustainable Tourism Management: A Bibliometric Analysis
}

\author{
Valentina Della Corte *(D), Giovanna Del Gaudio, Fabiana Sepe and Simone Luongo \\ Department of Economics, Management, Institution, University of Naples Federico II, 80126 Naples, Italy; \\ giovanna.delgaudio@unina.it (G.D.G.); fabiana.sepe@unina.it (F.S.); simone.luongo@unina.it (S.L.) \\ * Correspondence: valentina.dellacorte@unina.it; Tel.: +39-081-675-370
}

check for

updates

Citation: Della Corte, V.; Del Gaudio,

G.; Sepe, F.; Luongo, S. Destination

Resilience and Innovation for

Advanced Sustainable Tourism

Management: A Bibliometric

Analysis. Sustainability 2021, 13,

12632. https://doi.org/10.3390/

su132212632

Academic Editor:

Manuel Rodríguez-Díaz

Received: 30 August 2021

Accepted: 11 November 2021

Published: 16 November 2021

Publisher's Note: MDPI stays neutral with regard to jurisdictional claims in published maps and institutional affiliations.

Copyright: (c) 2021 by the authors. Licensee MDPI, Basel, Switzerland. This article is an open access article distributed under the terms and conditions of the Creative Commons Attribution (CC BY) license (https:/ / creativecommons.org/licenses/by/ $4.0 /)$.

\begin{abstract}
Over the years, literature on the topic of destination resilience has gained increasing attention in different fields (strategic management; sociology; etc.). Therefore, the potentiality of resilience in the tourism field has stimulated the definition and the implementation of strategies, policies, and activities addressed to mitigate risks and seize opportunities through open innovation attitudes in times of crisis. This work aims to contribute to the debate on tourist destination resilience by proposing a conceptual framework of destination resilience and open innovation based on a bibliometric analysis. Moreover, this article is intended as a starting point for a wider discussion of factors that contribute to destination resilience and therefore provides the basis to develop a toolkit of matrixes and approaches. Findings reveal that resilience assessment, as well as in terms of performance, remain undiscovered. Moreover, the present research poses some unresolved questions, shaping interesting future research directions.
\end{abstract}

Keywords: tourism; destination; resilience; innovation

\section{Introduction}

The post COVID-19 future will be characterized by companies that will maintain their business model and rely on an economic upswing, but also, by numerous companies that will not survive. Innovation is an imperative for organizational survival and success in the turbulent market environment of the tourism industry, especially in the current COVID-19 pandemic crisis [1-8]. Due to its complexity, the tourism industry is vulnerable to the impacts of major crises [9]. In this light, to face the increasingly devastating impacts of disasters, the use of the resilience approach is frequently suggested by multiple scholars as the best approach to respond to disasters [10]. More specifically, resilience is a concept with many different shades of meaning and with several disciplines employing their own definition and matrixes [11]. Generally, the term resilience refers to the intrinsic ability of objects, places, and people to absorb and recover from external stressors [12]. The concept was for the first time applied in the engineering research area and emphasized the ability of objects to resist to disturbance and quickly return to a given equilibrium state [13]. While there are multiple definitions of resilience, major variants of its concept include different perspectives and fields of application, such as ecological research, political sciences, organizational studies, etc. More specifically, the use of the concept in ecological research was introduced in the 1970s, with Holling [14] p. 14 defining ecological resilience as "the persistence of systems and of their ability to absorb change and disturbance, and still maintain the same relationships between populations or state variables", providing further momentum to its adoption as an analytical construct. Over the past few years, the resilience concept has been adopted in other research domains, including planning [15], psychology [16], organizational studies [17], political sciences [18], and urban studies [19-21]. Although there are several notions of resilience available in the literature, it is possible to identify two main approaches [16,22]. The first one considers resilience as a polysemic concept or a metaphor [23] and is defined as either an outcome 
or a process resulting from a triggering event whereby the affected entity returns to its original state. This approach is often viewed as an "engineering" approach to resilience. The second perspective regards the "ecological" or "socio-ecological" issues [13]. This approach focuses on all the aspects of resilience and their intrinsic abilities to maintain or adaptively change in the face of external factors. Starting from this, our attention shifts to the destination resilience concept, considering that, over the past few years, this issue has gained much interest and growing appeal in current tourism research, but there are still some discrepancies between the different contributions developed in the field [24]. Tourist destinations are difficult to define, but "they lie at the heart of much thinking about tourism and resilience". In this light, tourist destinations represent fertile soil to study the different notions of resilience. Based on the literature on the theme under investigation, there is no one-size-fits-all definition of resilience that can be indiscriminately applied. In fact, "the resilience of tourist destinations emerges from the many features of the tourist supply as well as from its demand. Therefore, a sound assessment of destination resilience requires comprehensive frameworks of analysis" [25] p. 107. In this direction, our research aim is to contribute to the debate on tourist destination resilience by proposing a conceptual framework of destination resilience and innovation based on a bibliometric analysis. The growth of tourism research has been accompanied by the publication of several bibliometric studies of the literature [26-28]. In contrast to narrative and systematic review, bibliometric analysis focuses on evaluating the research performance and contribution of individuals, publishing outlets, and institutions [28]. This article is intended as a starting point for a wider discussion of factors that contribute to destination resilience, providing the basis to develop a toolkit of matrices and approaches. Accordingly, we developed the following research question:

- What are the drivers that allow the development of a destination resilience framework based on innovation practices?

To investigate these issues, the paper is organized as follows: we first examined the literature review on destination resilience and its interconnections with the innovation approach; then, after presenting the methodology, as a sequence of methodological stages and a figure summarizing the whole process, we went through the explanation of the results, getting to the main findings. The paper ends with its conclusions, limitations, and hints for further research. Precisely, it develops useful insights that destinations stakeholders can use to measure their resilience in the optic of innovation for their tourism industry, for which very little empirical research exists. To the best of the authors' knowledge, the sample of this study synthesizes the largest selection of destination resilience articles in different journals as the methodology explains.

\section{Literature Review: Destination Resilience and Its Interconnections with the Innovation Approach}

Research on crises and disasters, as well as post-disaster responses, are central issues due to the frequency and scale of these events occurring over the most recent years. The rise of the resilience concept is emphasized by the most recent contributions showing that it is a hot topic above all in the tourism academic literature [29-33]. The resilience matter has been explored in a range of anthropogenic contexts, including recent applications in tourism [30], capturing increasing attention of academics and decision makers from various disciplines and sectors [34,35]. Analyzing the potential development of the tourism industry, it is necessary to consider the emergence of negative events and situations associated with climate change, crisis, political, social, and legal changes, and cultural circumstances [36-38].

The disruptive nature of disasters determines different implications for the tourism industry, for example, they impact transit routes and sources markets, by changing consumer perception of destinations as being safe [39]. The media amplifies this impact, creating the so-called "ripple effect", which spreads the impact of disasters across different geographical areas and economic sectors, as well [32]. This effect hinders destinations' 
recoveries as negative consumer perception of a disaster-affected destination hampers injection of foreign exchange, thus increasing the amount of time needed for the destination to recover [9]. Thus, managing disasters becomes of paramount importance in the optic of sustainable tourism. In such a context, it is clear that resilience requires reversal in posture from minimizing losses to creating value in the face of change orientation, toward constant learning and adaptation [40]. Each activity conducted in times of crisis imposes an open-minded attitude towards innovation, which improves the resilience capacity of an entity (organization, destination, the whole local tourism industry).

Different studies highlight that the tourism industry is more resilient than other sectors. Accordingly, some papers focus on a tourism-specific resilience indicator to measure the ability of tourism markets to replace domestic tourism flows with international ones [41-43]. In this direction, the majority of papers focus on both adaptation and reaction to natural disasters, economic crises, pandemic events, and climate change, while few contributions aim at creating a rigorous and holistic measurement framework in order to manage and develop the destination in a resilient perspective by leveraging an open innovation approach. Specifically, this paper is related to innovation, conceived in the optic of "open innovation" because it concerns the ability of a destination to create and integrate value added products that help to maintain the position and market share and/or improve it in the long run [44]. Since tourism products are the result of a co-creation approach, the adoption of open innovation can offer added value for tourists and a collaborative basis among the actors of the tourism industry and other stakeholders involved [45].

In general terms, the tourism literature related to destination resilience emphasizes a destination's ability to adapt, learn, and self-organize after disasters. Specifically, the extant research on destination resilience has demonstrated that, as destinations are varied in structure and resources as well as in the extent of disastrous events, the speed at which destinations recover depends on their capacity to adapt to the external turbulence [32]. Moreover, as underlined by Hall et al. [25], it is possible to distinguish two different dimensions of destination resilience: macro-dimension and micro-dimension. The first one relates to the social-ecological aspects of destination resilience, giving a destination-wide view of the tourism systems and how they adapt to disasters [46], while the micro-dimension concerns the individual networks within the larger system, covering areas such as businessspecific resilience [47]. In line with these assumptions, extant research reveals that destination resilience depends on the resilience of all subsystems within the destination [25] and should regard planning and sharing of resources via stakeholder collaboration. Properly, tourism stakeholders should collaborate with the goal of building disaster resilience at a destination level, building their own, internal resilience. This is known as organizational resilience [48]. Therefore, building overall resilience at a destination level relies on collaborative actions the destination managers/policymakers are able to develop. Consistent with the open innovation paradigm, conceived as "the use of purposive inflows and outflows of knowledge to accelerate internal innovation, and expand the markets for external use of innovation, respectively" [49] p. 2, destinations are open and flexible in terms of the actors and the resources they involve, have flexible notions of what constitutes tourism, and also actively promote the sharing of data and other resources [50,51]. They practice openness and sharing through open data and open innovation initiatives. The opening of data banks, and of infrastructure together with the notion of sharing and co-creation facilitate new levels and types of connectivity, which Hartman [52] described as an important condition to achieve destination resilience. An important resilience issue is the ability to communicate with tourists and other stakeholders immediately before, during, and in the aftermath of a crisis [53]. In this view, open innovation and creativity are fundamental elements of the tourism ecosystem at destinations and are actively supported by the technological and governance layers. Being able to develop as well as implement innovative solutions to address long-term problems, like overtourism, creating pathways to innovation, in terms of established partnerships, available data and technological infrastructure are aspects of destinations that clearly support the resilience issue. Hence, like resilience requires the 
incorporation of "thinking in adaptive systems" [52], destination management requires a smart tourism mindset embracing technological connectivity, flexibility, creativity, and openness that needs to permeate all development strategies.

\section{Methodology}

In this study, we perform a bibliometric analysis which is a robust methodology, due to its degree of objectivity, used in many disciplines, that allows systematization of scientific production on a theme, by making sense of large volumes of unstructured data in rigorous ways [54-57]. As regards the use of bibliometric analysis for the topic of destination resilience, there already exist academic contributions [58,59]; nonetheless, the attention and novelty of this research lies in the precise topic of destination resilience with specific reference to the open innovation paradigm, considering that the destination resilience literature could greatly benefit from adopting a more open-innovative viewpoint, also integrating smart tourism principles into its frameworks. This study has been conducted through Bibliometrix, an R-package software (Massimo Aria, Department of Economics and Statistics, University of Naples Federico II, Naples, Italy) which allows bibliometric analysis using the $\mathrm{R}$ language $[60,61]$. This is an open-access software which provides many functions to perform quantitative analysis both in bibliometrics and scientometrics research [59]. Other advantages include avoiding the use of additional software, since it also provides a set of tools for data visualization and ensures statistical correctness and completeness of results $[62,63]$. Bibliometrix is spreading in many domains of academic research such as economics [64], business and management [63,65,66], tourism and hospitality [67-69], open innovation [70], politics [71,72], and psychiatry [73]. Our work is conducted following a precise bibliometric workflow (reported in Figure 1): data collection, data analysis, and data visualization [59].

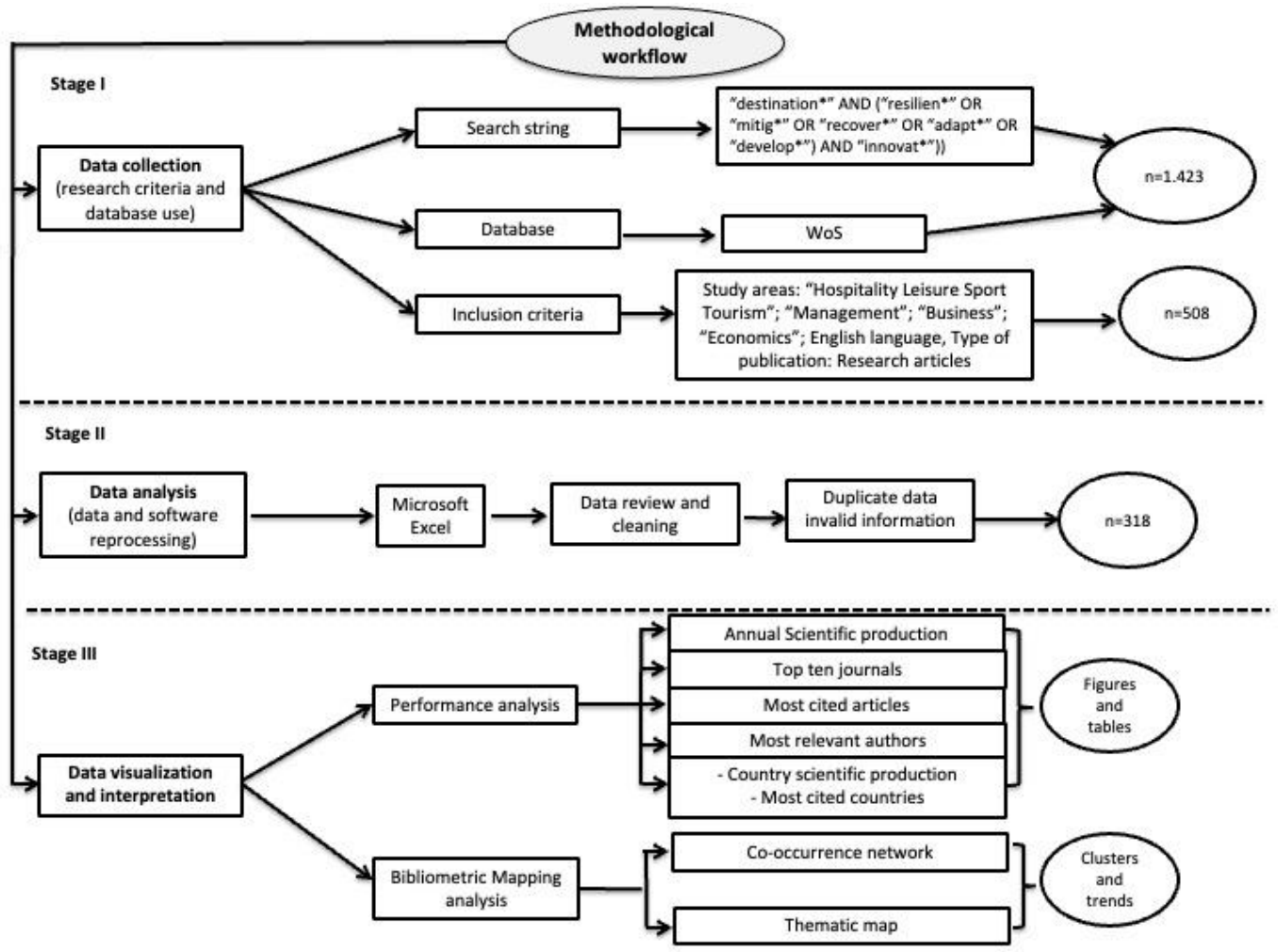

Figure 1. The bibliometric workflow.

\subsection{Data Collection}

We used Web of Science Core Collection database to collect the articles on which our research is based with the following keywords, considered as the most pertinent: 
"TS= (("destination *" AND ("resilien *" OR "mitig *" OR "recover *" OR "adapt

*" OR "develop *") AND "innovate *"))".

These precise keywords have been chosen for delimiting our research field. Indeed, the word "destination" has been selected in order to define our research stream while the words "resilien *", "mitig *", "recover *", "adapt *", "develop *" to better discover the behavioral attitudes of destination in time of crises, using different synonyms suggested by the referring literature $[35,41,46,71,74-76]$. Furthermore, the word "innovate *" has been added to verify whether and to what extent firms have adopted innovative solutions and behaviors. We used the word "innovate *" rather than "open innovate *", because we considered different pathways to innovation, in terms of partnerships (systemic innovation), data sharing, digital solutions, and experiential innovation, as fundamental conditions, strictly linked to the open innovation paradigm.

Clarivate Analytics' Web of Science is the worldwide leading database for academic purposes $[77,78]$. This platform covers a broad range of scientific tasks across several knowledge domains $[79,80]$ and it is traditionally accepted as the exclusive and largest accessible database for bibliometric analysis [81-83]. It is used both as a research tool as well as a dataset for large-scale data intensive studies [79]. The present study has been carried out using documents released in May 2021. The asterisk was used to retrieve alternative forms of a term according to its root, for example its singular/plural form (i.e., destination or destinations; innovation or innovative). Keyword research was conducted in the Web of Science (WoS) "topic" section, which involves title, abstract, author keywords, and Keyword Plus. Initially, the search generated about 1.423 documents. WoS filters were used to narrow the search field. The first one was applied for categories, selecting: "Hospitality Leisure Sport Tourism", "Management", "Business", and "Economics". These subjects are in line with our research purposes. Other filters concerned the type of document and the language, searching for only research papers and in English language. Our decision was based on the assumption that English is the common language of science or the most used language of scientific publication [84] and it is widely considered as the "lingua franca" for academic purposes also among non-Anglophone researchers [85,86]. After the gathering process, the total number of papers decreased to 508.

\subsection{Data Analysis}

Thereafter, the abstract of each publication was carefully analyzed by all authors, excluding 190 records; specifically, in the excluded works, in addition to duplicates (2) and those not study-related (113), the concept of destination diverged from the tourist perspective. In these works, the destination was conceived as the location of exports (25) as well as foreign investments (32) or discussed in the migration context (18). The final database consists of 318 articles. This work uses some inference methods to investigate into dataset, sources, documents, and literature conceptual structure.

\subsection{Data Visualization}

Visualization techniques are used to represent a science map and the outcomes of different analysis [61]. As Jiang et al. [58] state, bibliometric visualization tools provide additional insights within a literature area by improving communication of results, supporting data analysis, and offering meaningful information to readers. In this study, data are examined using performance analysis and science mapping [56]. Performance analysis is considered a standard practice in reviews [54]. While this bibliometric approach allows us to present and assess the activity of research constituents (e.g., countries, journals, authors) and their impact [87], science mapping pertains to both intellectual and structural relationships among scientific actors [54], by determining the cognitive structure of the research domain [56,87]. We consider the annual scientific production, top ten journals by number of publications, most cited articles, most relevant author, scientific production by countries, and most cited countries as measures for performance analysis. Science mapping analysis concerns the co-occurrence network and thematic map. 


\section{Results}

Firstly, in order to have a more comprehensive outline of the destination resilience linked to the open innovation paradigm, we conducted a systematic literature review searching for the most relevant and more influencing papers in the current academic debate. Accordingly, our literature review reveals that $65 \%$ out of 318 papers are conceptual, while $35 \%$ are empirically based (Figure 2). In the case of empirical papers, most of them concentrate on qualitative research, emphasizing the multi-case study approach. In detail, most of the contributions are based on the study of specific crisis events taken individually, pursuing a governance-based approach. Economic crises and natural disasters are the main phenomena investigated while the units of analysis are principally macro-aggregates, such as a country, a specific destination, or the whole tourism industry. Some publications aim to contribute to the resilience topic by advancing measurement models and offering disparate indicators [88], but only few of them conduct empirical validation of the proposed resilience indexes [35] providing quantitative insights. The most suggested and adopted ones include economic indicators, social indicators, institutional indicators, infrastructure indicators, and community indicators [35,83,89].

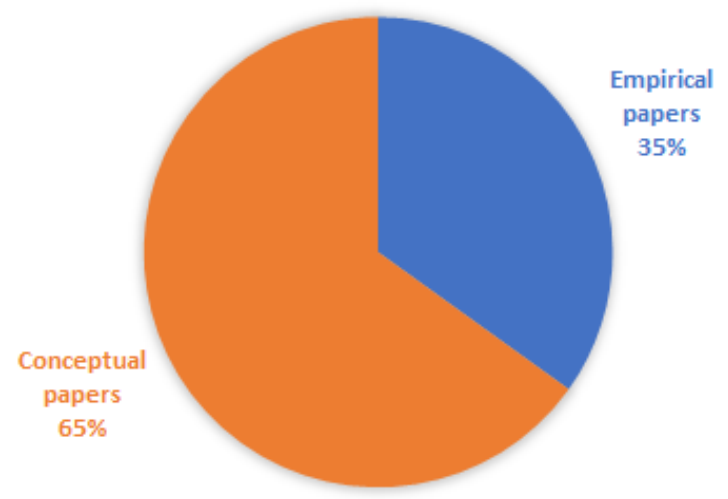

Figure 2. Conceptual vs. empirical papers.

In order to strengthen the interconnection between the destination resilience and the open innovation approach, this article uses a bibliometric analysis. It seems to be very interesting to investigate the parallels between the concept of destination resilience and open innovation principles and therefore to suggest that further conceptualizations and empirical research at the intersection of the two topics could greatly inform theory and practice in both areas. For instance, while there is great research on open innovation in tourism [90], the main drivers and outcomes of open innovation have not been examined yet, above all not at the destination level and not with respect to the notion of destination resilience. The next section discusses the literature trend from 1998 to 2021.

\subsection{The Evolution of Scientific Production}

With reference to the following graph (Figure 3), in relation to the topics addressed in this study, there is a growing research trend. We divided the timeframe in three time flows according to turning points identified in the literature evolution over the years. These turning points concern the contraction or increase in scientific production as well as shifts in the topics addressed. After the first period (1998-2004), characterized by only five contributions, scholarly attention has increased since 2005, reaching a peak in 2020. The only years in which there was a slight contraction were 2015 and 2016. During the second period (2005-2014) 100 articles have been published. The themes of destination management, innovation and sustainability begin to assume a central role in the literature. With reference to destination management and governance research, i.e., [91-94], the fourth most cited article [95] explores the role of networks between local government and industry in creating public-private partnerships, identifying managerial implications in tourist destinations through a case study. Several studies are addressed to 
the innovation, i.e., [96,97] and sustainable development, i.e., [98-100] topics. Within the context of cultural tourist destinations and based on the results of the ISAAC European project, a study covers both subjects [101]. Authors deal with technical and organizational innovations in the implementation of integrated e-services, which allow to improve access and fruition of local and cultural heritage, promoting sustainable development that benefits the whole community. Other studies deal with topics related to the issue of sustainability. Among these, a contribution discusses the centrality of mobility in sustainable destination planning [102]. Findings reveal that innovations oriented to sustainable forms of transport are justified because of social, environmental, and economic impacts of tourist traffic.

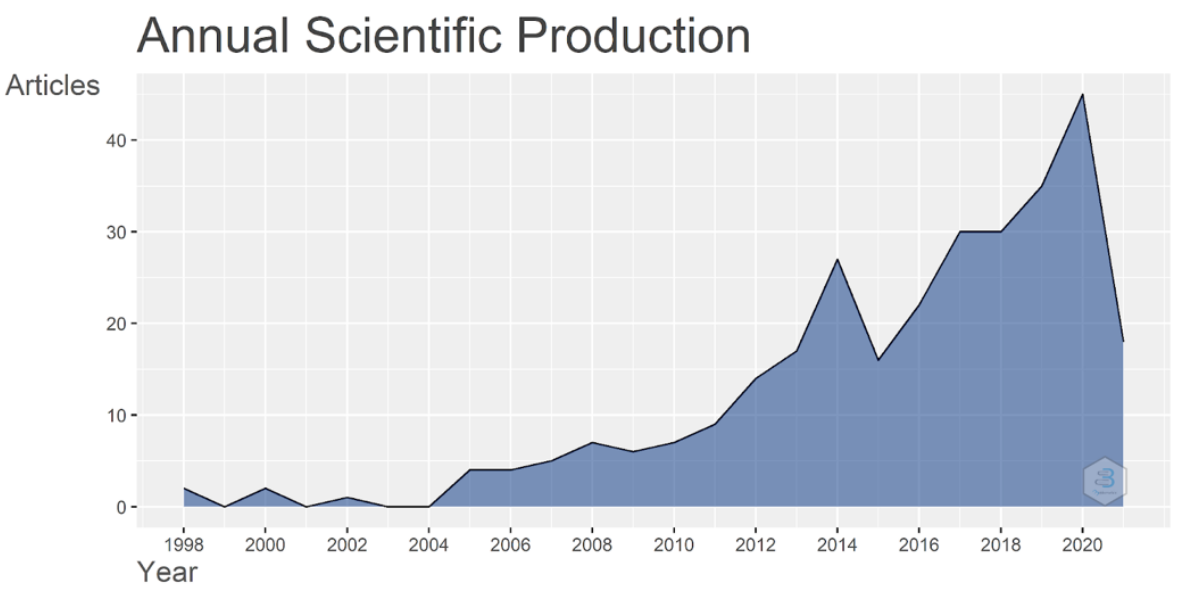

Figure 3. The annual scientific production from 1998 to 2021.

The third scientific production period (2015-2021) counts 213 contributions. The themes of innovation and sustainability, resilience, e.g., [51,103-110] and its related topics, such as disaster and crisis recovery, i.e., [104-108]; climate change, i.e., [111-114]; and overtourism, i.e., [115-117], start to emerge. Other papers stress the attention on smart destinations. Among these, the most cited article [118] defines the fundamentals of the smart tourism concept and discusses its potential and disadvantages.

\subsection{Distribution of Scientific Production in Journals, Most Cited Articles, and Main Authors}

The academic production of the papers included in our database appears fragmented. The total number of sources is 103 and the top ten journals have published 127 articles, representing $40 \%$ of the entire sample (Table 1 ). In our opinion, this is probably due to the general interest of tourism scholars in the topics under investigation, emphasizing their pivotal role in the field-specific literature.

Table 1. Top ten journals.

\begin{tabular}{cccc}
\hline Sources & N. of Articles & Impact Factor & H-Index \\
\hline Journal of Sustainable Tourism & 21 & 7.96 & 103 \\
Tourism Management & 17 & 10.96 & 199 \\
Tourism Review & 17 & 4.45 & 32 \\
Journal of Destination Marketing \& & 15 & 6.95 & 39 \\
Management & 14 & 6.89 & 74 \\
Current Issues in Tourism & 10 & 3.79 & 58 \\
International Journal of Tourism Research & 9 & 2.60 & 12 \\
International Journal of Tourism Cities & 8 & 10.98 & 132 \\
Journal of Travel Research & 8 & 1.47 & 36 \\
Tourism Analysis & 8 & 6.64 & 61 \\
Tourism Geographies & &
\end{tabular}


This is also evident from the aim and scope of the principal sources, which cover different subjects. The Journal of Sustainable Tourism (H-index: 103) promotes the understanding of sustainability and its relationship with the tourism industry by stimulating the scientific debate and pursuing a multidisciplinary approach. Tourism Management, the journal with the highest H-index (199) in the Tourism, Leisure, and Hospitality Management subject category on Scimago and Journal of Destination Marketing and Management (H-index: 39) deal with management, planning, and marketing of travel and tourism. Tourism Review (H-index: 32) and Current Issues in Tourism (H-index: 74) are generalist journals, which cover a wide range of themes within the tourism field. The last five positions are occupied by International Journal of Tourism Research with ten articles, followed by International Journal of Tourism Cities with nine articles and, at last, Journal of Travel Research, Tourism Analysis and Tourism Geographies with eight published articles. In general, all these journals encourage multi and interdisciplinary debates disseminating novel and creative approaches and methods to foster research. The first eight journals are the core sources as they published about a third of the papers included in the database. Furthermore, bibliometric tools allow for a list of the most cited articles (Table 2); in this research, these represent leading tourism-specific contributions.

Table 2. Most cited articles.

\begin{tabular}{cc}
\hline Articles & Total Citations \\
\hline Gretzel U, 2015, Electron Mark & 392 \\
Buhalis D, 1998, Tourism Manage & 384 \\
Hjalager Am, 2002, Tourism Manage & 352 \\
Dredge D, 2006, Tourism Manage & 320 \\
Vogt Ca, 1998, Ann Tourism Res & 273 \\
Dwyer L, 2009, Tourism Manage & 229 \\
Lamming R, 2000, Int J Oper Prod Man & 208 \\
Neuhofer B, 2012, J Destin Mark Manage & 199 \\
Oskam J, 2016, J Tour Futures & 194 \\
Buhalis D, 2005, Tour Recreat Res & 163 \\
\hline
\end{tabular}

The research domain of destination resilience and open innovation is addressed by a large number of authors. In fact, 694 scholars have contributed to the 318 articles, of which only 58 contributions can be considered as single-authored documents. Specifically, only 8 authors published at least 4 publications (1.2\% of total authors), followed by 8 authors which contributed with 3 papers (1.2\% of total authors), 60 authors of 2 publications (8.7\% of total authors), and lastly 618 authors with just one work (89\% of total authors). These ratios indicate a low concentration in this field of study. The authors per document index is 2.18 , the co-authors per document index 2.52, while the collaboration index is 2.47 . The top contributors, according to the number of published papers, are presented in detail in Figure 4. The most prolific authors are D. Buhalis, A.M. Hjalager, and H. Pechlaner. By the use of WoS citation report function, we collected information about the number of published works over the years, the citation average per item and the H-index. This is a measure of the productivity and citation impact of the publications of a scholar [119]. Buhalis D. is the author who contributed to the academic research with 140 publications from 1993 to date. This author, affiliated with Bournemouth University, is an expert in the subject of strategic management and marketing with a particular interest in the application of ICT in the tourism and hospitality industry. His citation average per item is about 70 and the $\mathrm{H}$-index is 45 . He is followed by Hjalager A.M. from the University of Southern Denmark. Her main research priorities concern tourism and rural development. Since 1996, she has published 57 contributions. This scholar has an average citation per article of 34 and the H-index is 16. The last of the top three contributors is H. Pechlaner from the Catholic University of Eichstätt-Ingolstadt. His research interests are related to entrepreneurship and destination management and governance. This author contributes to scientific debate with 106 publications and the H-index is 22 . 


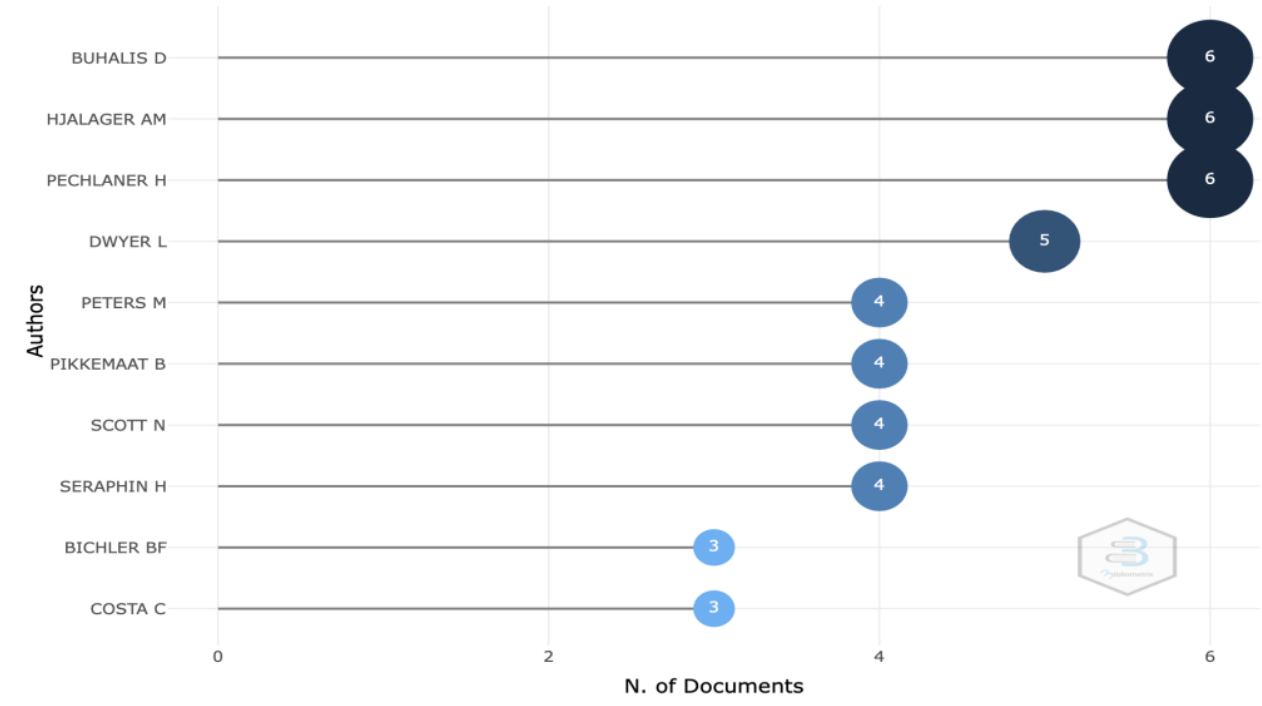

Figure 4. Most relevant authors.

\subsection{Contributions and Citations by Country}

Figure 5 reports the global scientific production by country, in which the color tends to change according to the number of published works. The extant literature is provided by 62 contributing countries, for a total of 664 frequencies. The most productive country is the United Kingdom that covers 68 documents, representing $10.2 \%$ of the whole sample. It is followed by Spain and Australia with respectively $65(9.8 \%)$ and $62(9.3 \%)$ articles. Italy is the fourth country in the list, with 51 contributions $(7.7 \%)$. Next in the ranking are the United States (47; 7.1\%), China (44; 6.6\%), Portugal (39; 5.9\%), and The Netherlands (24; $3.6 \%$ ). In addition, there are 54 countries which contribute to this field of study with less than 24 documents, representing $40 \%$ of total frequencies. Comparing these data with the number of citations per country (see Figure 6), the top 5 contributors are also the most mentioned. The United Kingdom is the country with the largest number of citations (1550), 688 more than Australia (862) and nearly triple the citations of the USA (569), Spain (533), and Italy (468). Although Denmark (435), Korea (403), Canada (246), and Slovenia (204) do not appear among the main contributors, these are some of the ten most frequently cited countries. The Netherlands is placed ninth with 241 mentions.

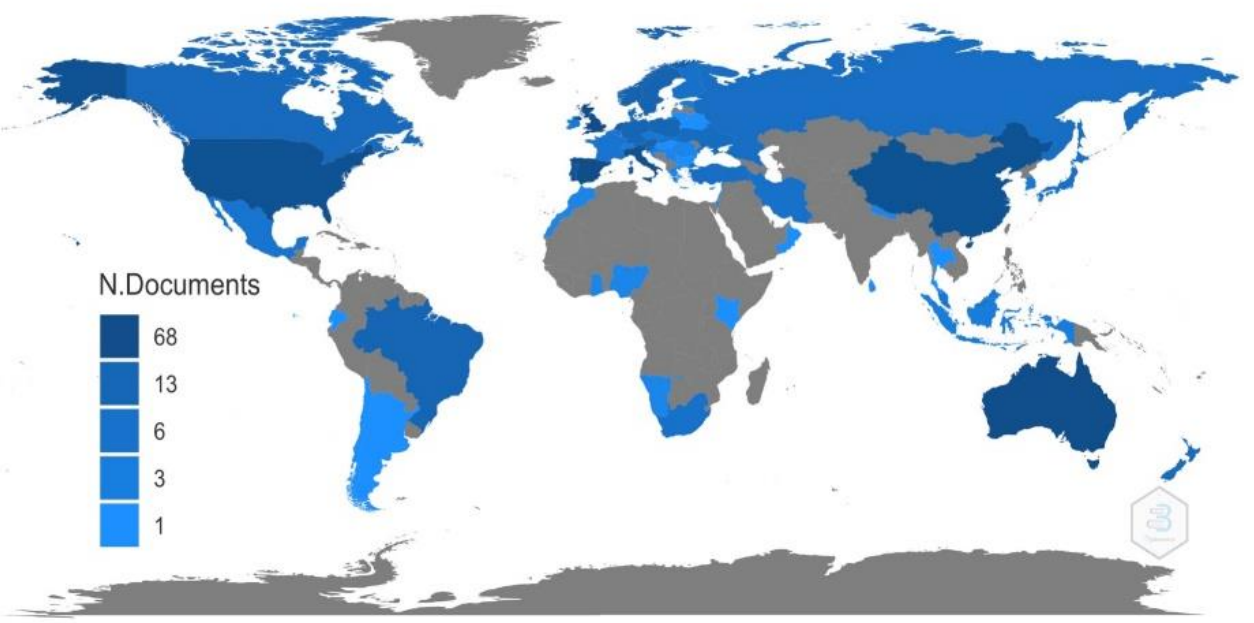

Figure 5. Scientific production by country. 


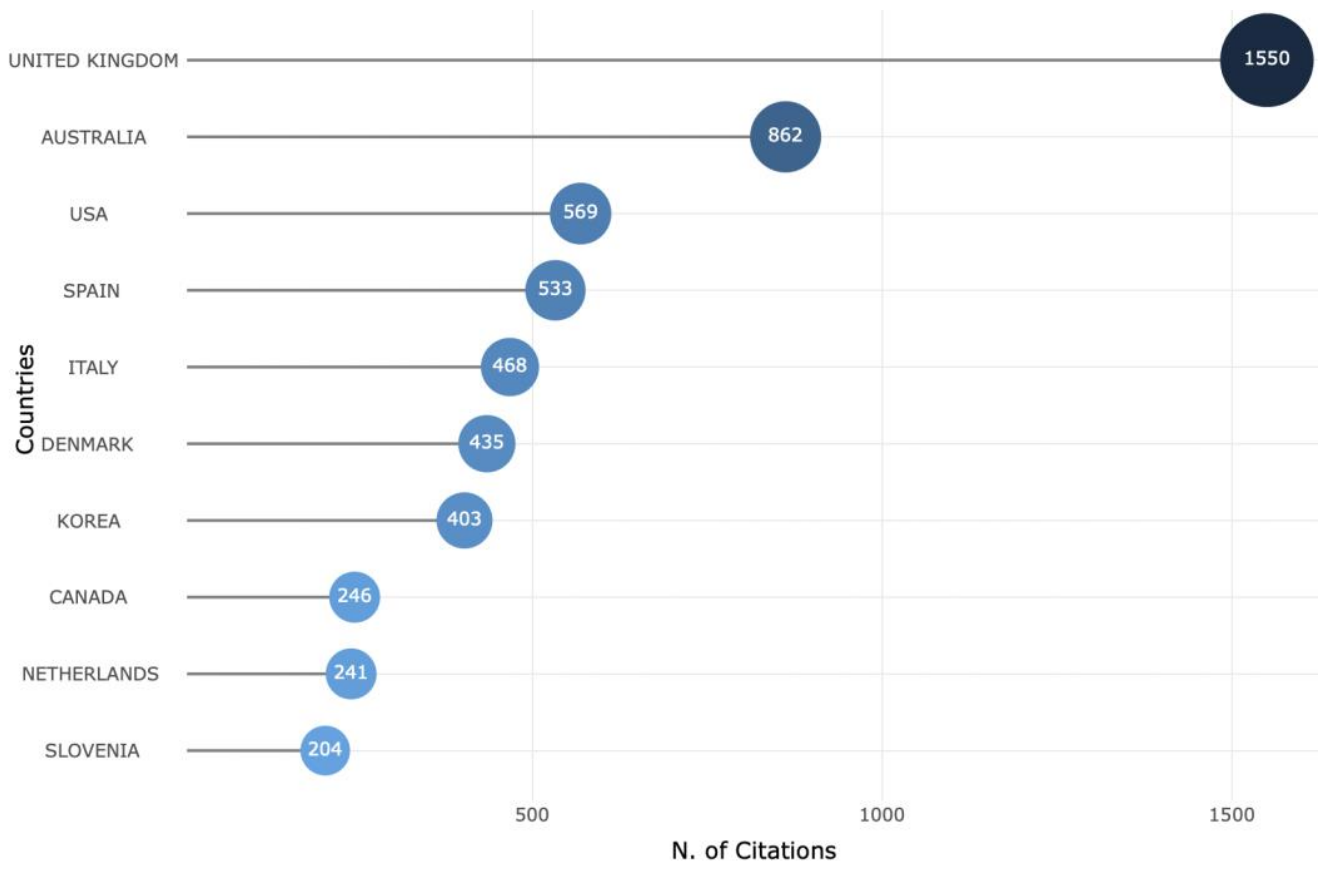

Figure 6. Most cited countries.

\subsection{Conceptual Structure: Co-Occurrence Network and Thematic Map}

The keywords used to conduct our analysis are suitable for the study purposes, since these allow us to answer the research questions. The co-occurrence network allows to evidence the conceptual structure and the most recurrent issues in the examined themes. Specifically, co-occurrence analysis was used to detect the most frequently occurring keywords and to identify trends and emerging research topics. Figure 7 shows the keyword co-occurrence and clusterizes the main concepts coming from the papers. This constitutes the conceptual structure of our research field. The results indicate that research on destination resilience and open innovation regards topics: innovation, management, performance, destination, tourism, and networks. This finding, given the generic nature of these words, reveals that tourism-related literature is still in an embryonic state in the fields of resilience and innovation. These concepts have not been thoroughly investigated yet and appear to be linked by traditional management keywords that are associated with: competitiveness, strategy, model, experience. Some words seem too broad, such as management and performance; this is explained by the selection criteria used to retrieve contributions in management, business, and administration subjects, which are associated with business performance. Other interesting words, such as collaboration and networks, are related to resilience, as the ability to cope with crises, and connected to coopetition strategies. This result paves the way for future compelling research opportunities. Other significant themes emerge from our work, namely, technology, sustainable tourism, absorptive capacity, dynamic capabilities, and knowledge concerning firms or destination resilience capacity.

Figure 8 illustrates the thematic map, which exploits the KeyWords Plus field. Those keywords are associated by Thomson Reuters editorial experts supported by a semiautomated algorithm. They review the titles of all references and highlight additional relevant but overlooked keywords that were not listed by the authors. Differently from the authors' keywords, the Keywords Plus field is normalized. Keywords Plus terms are able to capture an article's content with greater depth and variety [120]. The thematic map, also known as strategic diagram, shows the main detected themes, categorizing them in four classes according to their Callon's density and Callon's centrality measures [121]. The centrality represents the importance of the topic and the density indicates how the topic is developed according to quantitative terms [61]. As Cahlik describes [122] p. 375. 


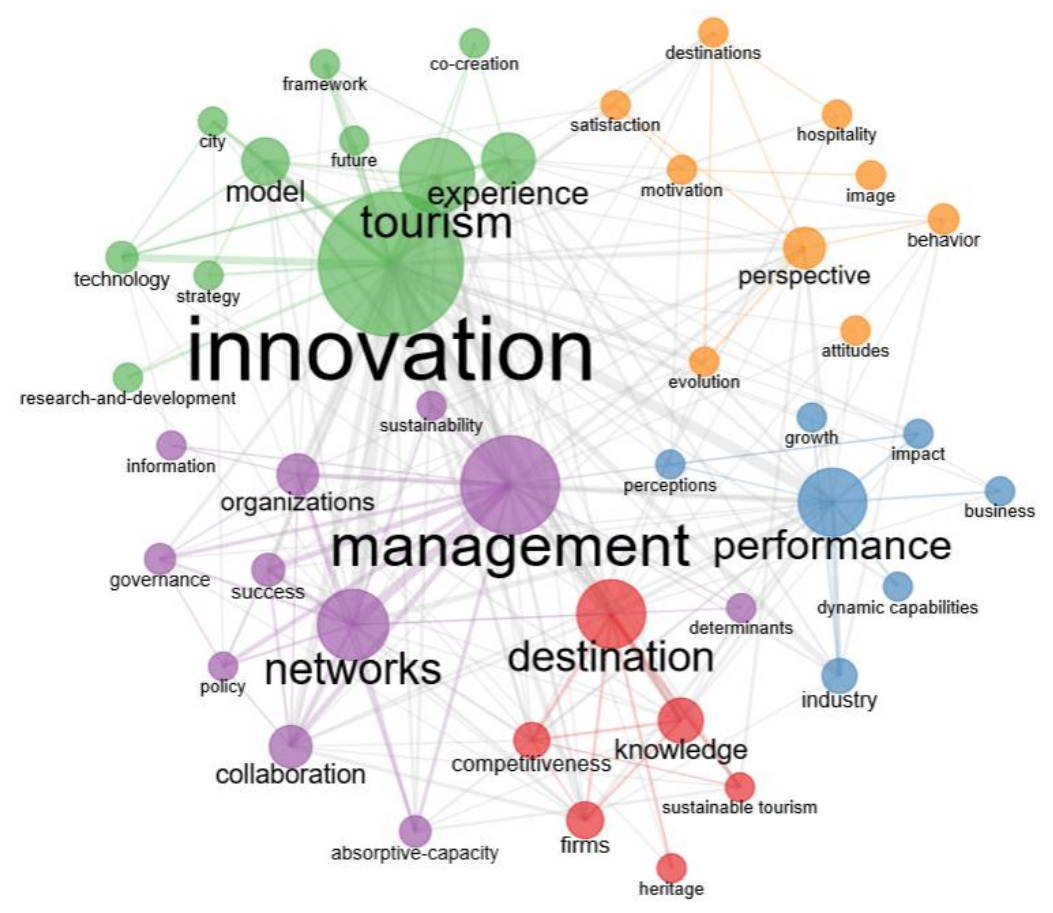

Figure 7. The co-occurrence network.

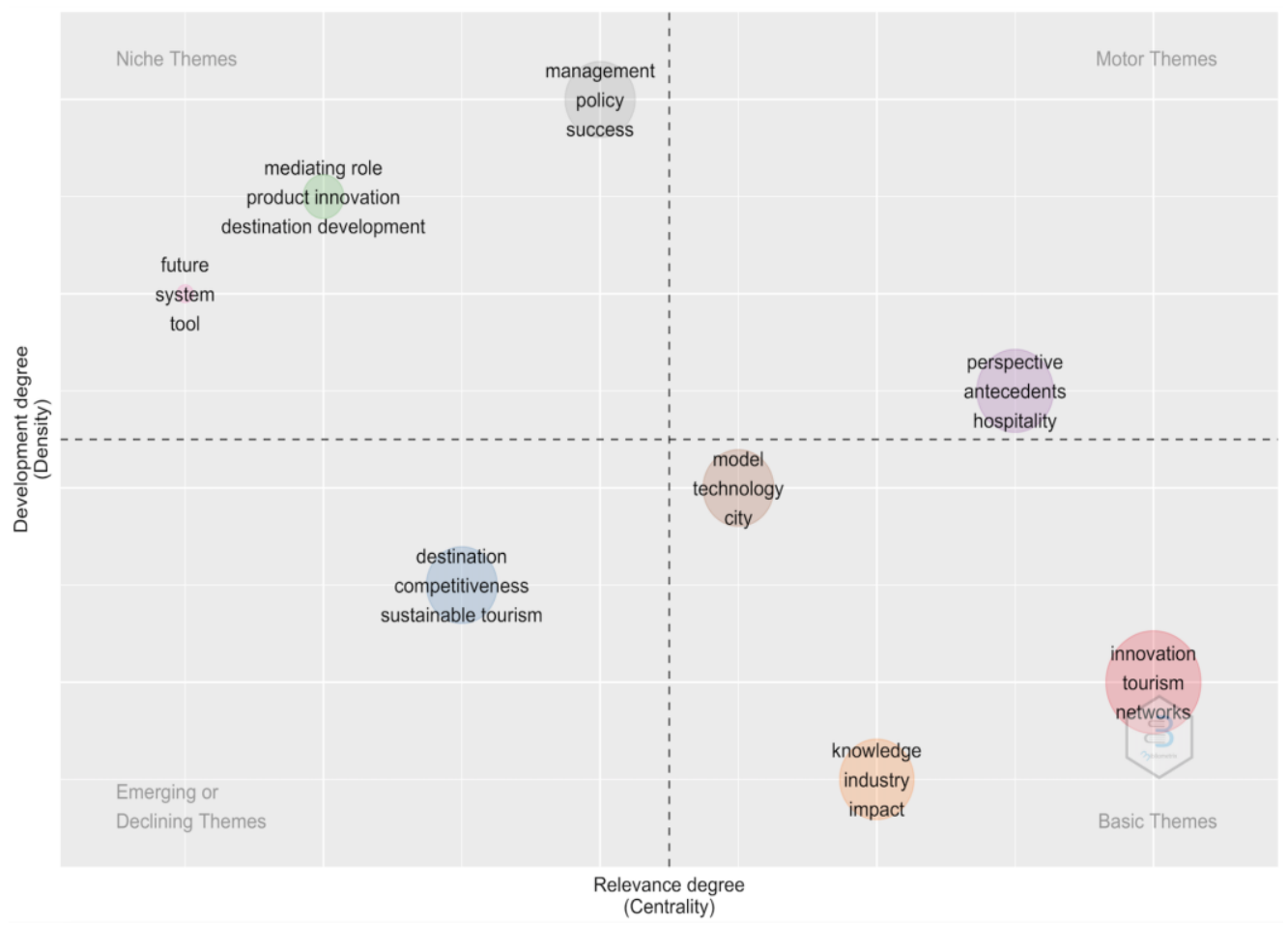

Figure 8. Thematic Map.

- Motor themes (upper-right quadrant): Hospitality, antecedents, and perspective even if they are developed and relevant themes, they are almost general. For their high centrality and density, these are the main matters for the structuring of a research field.

- Niche themes (upper-left quadrant): Product innovation and destination development/management are only of a marginal importance for the field of study because these have well developed internal ties but unimportant external ties. So, these themes have a high centrality but a low density. 
- Emerging or declining themes (lower-left quadrant): Sustainable tourism is slightly developed and marginal. This topic is still in an embryonic state of study with the topic of destination resilience and innovation.

- Basic themes (lower-right quadrant): Model, technology, city/innovation, tourism, networks/knowledge, industry, impact are themes with low density and high centrality that are transversal in the research area.

\section{Discussion}

Based on literature review and bibliometric analysis and in order to answer our research question aimed at understanding what are the drivers that allow the development of a destination resilience framework in an open innovation realm, we propose a resiliencebased conceptual framework by providing a set of drivers of destination resilience that can lead to the adoption of useful post-crisis recovery strategies in the optic of sustainable tourism development. As emerges from Figure 9, technology (as also emerges from the thematic map) represents a major force in creating flexibility in the tourism industry [2]. Crises and disasters help in speeding up changes in technology. Robots replacing people, applications on mobiles being employed to track people's contacts, artificial intelligence devices or Big Data analytics forecasting are only few examples of technologies spread among the masses. In particular, during COVID-19, people have taken massive aid from technology experts. Thus, technology can handle pandemic-specific issues such as screening travelers, ensuring online education for students, etc. [2]. Some contributions show people willingness to change their attitudes toward technology [123-125]. In this direction, [126] propose the "six transformative e-tourism research pillars" for bringing in changes in e-tourism by proactively using IT resources for short-term and long-term purposes. [127] argue that high growth and progressive regions differ in their culture that promotes innovation. This attitude is due to their absorptive capacity, which they define as the combined ability of firms and individuals within the region to recognize, assimilate, and commercialize external knowledge or knowledge generated elsewhere. The factors and organizational capabilities which influence and foster absorptive capacity within tourism businesses are deeply investigated [128]. According to the authors, absorptive capacity enables the achievement of a competitive advantage, leading to a firm superior performance. This stream of research supports the existence of a positive relationship between inter-firm cooperation, dynamic capabilities, competitive advantage, and company performance [129]. Therefore, absorptive, innovative, and adaptive capabilities are the outcomes of interorganizational cooperation. The importance of innovation tourism networks (as resulted from the thematic map) in the tourism field has been widely highlighted in the literature. In the context of coastal tourist destinations, a contribution points out the international dynamics that seaside territories should implement within innovation networks [130]. Specifically, authors argue that to improve territorial attractiveness and competitiveness, markets and products innovation and diversification play a central role. At least, expert knowledge and experience, in terms of knowledge industry impact [131,132] need to be put into practice for shifting toward destination resilience. As for the post-crisis responses, it is evident that the recent times are the most suitable for promoting a sustainable tourism industry [133]. This one needs to be oriented toward education, environmental and social justice, and racial healing. The tourism industry's players need to be encouraged to push a new demand by changing their unsustainable product offers. Such measures can connect, support, and take care of the whole tourism industry to everyone's advantage $[134,135]$. Sustainability represents an on-going procedure to attain positive outcomes and is defined by changing beliefs, wishes, information, skills, and public awareness [136]. 


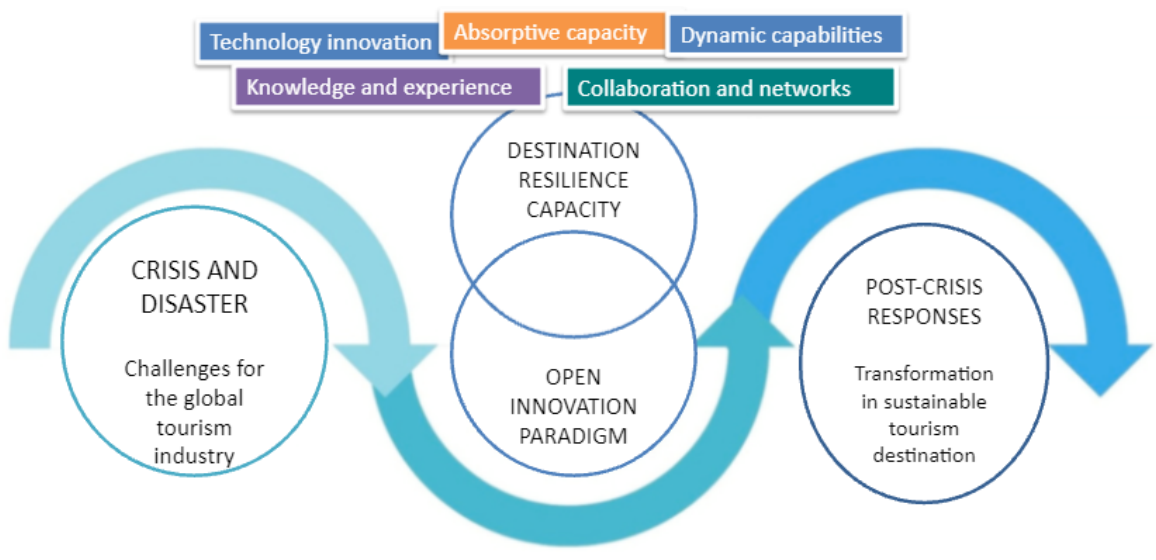

Figure 9. Destination resilience-based framework.

While the variety of models in the extant literature highlights a particularly interesting area of research, the absence of universally recognized models raises some questions that can be addressed in the future research. Since the disaster triggers depend on a wide range of causes and the response can require a different mix of competences and supplies [137], we consider as the main obstacle to create a robust and integrated model the difficulty of synthesizing the multitude and heterogeneity of variables. Furthermore, the identification of appropriate parameters is complex and their monitoring costs are daunting [138]. While tourism development for local communities is expected to contribute to the economy, improving social welfare and preserving local culture [139], tourism destinations are significantly vulnerable to shocks [140]. Resilience to disaster events is mainly associated with risk mitigation, cost minimization and impact reduction rather than with the ability to cope with change by seizing opportunities. This is particularly relevant if we consider that the tourism industry is a good example of a complex adaptive system [141]. In a transitional phase, entrepreneurs need to create new value for customers and new markets [142]. Considering an organization as a value creation source, both innovation and knowledge creation assume relevance $[143,144]$. Making a destination more dependent on innovation seems at first sight counterproductive to achieving greater resilience as innovation adoption can add different kinds of vulnerabilities [144]. As Hartman specifies in his work [52], it is desirable to develop, as well as efficiently implement, innovative solutions to address long-term issues like overtourism. For instance, pathways to innovation, partnerships as systemic collaborations, data sharing, and pervasive technological infrastructure are fundamental conditions, strictly linked to the open innovation paradigm [145] that clearly support destination resilience. Creativity and innovation are seen as key components in company and destination management strategies [146]. To date, surprisingly little is known about the complex drivers of destination resilience, leading to the creation and application of ineffective resilience-building solutions. Of course, the vulnerability of tourism destinations to socio-economic and environmental shocks (rapid-onset events) and stressors (slow-onset events) is widely recognized [147]. Long-term resilience-building activities aimed at securing future sustainable tourism cannot be operationalized successfully without understanding and addressing the underlying drivers that form the foundations of destination resilience in the optic of open innovation.

\section{Conclusions, Limits, and Hints for Further Research}

This paper contributes, according to both a theoretical and practical point of view, to the scientific production on the theme under investigation by suggesting a coping-up mechanism, which revolves around resilience. However, considering the extant literature, the assessment of this attitude, as well as in terms of performance, remain unclear. Specifically, there are some unresolved questions that can represent the starting point for further research. Firstly, it would be interesting to understand how destination resilience 
should be analyzed and evaluated. In this direction, it could be useful to study if economic indicators, such as balance sheet ratios, could be used to measure resilience capacity. Nonetheless, apart from economic indicators there is a need to develop indicators aimed at measuring soft capabilities, which currently cannot be identified. Another important issue to be addressed regards the time period in which the resilience capacity should be measured (e.g., one year after the crisis?). An extensive part of the research carried out so far is devoted to prevention, scenario creation, and preparation of contingency plans. In this direction, the approach to post-crisis recovery strategies has been dispersed and unstructured. Hence, most studies on the issue under investigation fail to adopt a more holistic perspective. In addition, practitioners within the tourism destination have yet to realize the importance of risk and crisis management planning due to the lack of theoretical and conceptual frameworks addressing this issue. To close significant research gaps in the tourism management field, we consider both necessary and interesting for future research to investigate firms' post-crisis recovery even to define measures (variables, indicators) in order to include a corporate dimension in resilience assessment models and to clarify how value creating business conducts contribute to system-wide resilience improvement. Our study highlights a growing need for new resilience approaches considering the locationspecific characteristics of the tourism industry, its relevance to the local economy, and the hospitality supply chain strategies. This is very important in the optic of the actual situation because it is clear that during the pandemic all destinations were going through a difficult period, but it is also true that as a post-COVID 19 response, destination managers are focusing attention on tourism as a source of development (as highlighted also by the budget allocation for sustainable and social tourism). Hence, according to this view and in the wake of the pandemic, we propose a destination resilience-based framework for reviving the global tourism industry post-COVID 2019.

This work presents some limitations. First of all, we conducted our study using certain tools of bibliometric analysis, so we suggest for future research to deeply investigate the social and intellectual structure, through other bibliometric instruments. The second limitation concerns the type of documents included in this work. We gathered only in WoS database topic-related papers written in English, excluding conference proceedings, book chapters and doctoral theses. Furthermore, future studies should select additional keywords properly connected to resilience and open innovation in management and hospitality subjects. Finally, we advise the complementary use of other research techniques (i.e., content analysis) for a better understanding of examined issues and to improve the quality and relevance of the bibliometric outcomes. In order to make them generalizable and to test the validity of the proposed destination resilience framework, we consider a cross-country empirical study to be helpful. However, this article reveals that, at the conceptual level, there are many parallels between the notion of destination resilience and open innovation principles and therefore suggests that further conceptualizations and empirical research at the intersection of the two topics could greatly inform theory and practice in both areas.

We hope this article will serve as a stepping stone towards such greater integration of destination resilience concepts and open innovation practices, encouraging research that bridges the two subjects.

Author Contributions: Conceptualization, V.D.C. and F.S.; methodology, S.L.; software, G.D.G.; validation, V.D.C.; G.D.G.; F.S.; S.L.; formal analysis, S.L.; investigation, F.S.; resources, G.D.G.; data curation, F.S. and S.L.; writing—original draft preparation, V.D.C.; writing—review and editing, V.D.C.; G.D.G.; F.S.; S.L.; visualization, F.S.; supervision, V.D.C.; project administration, V.D.C. All authors have read and agreed to the published version of the manuscript.

Funding: This research received no external funding.

Institutional Review Board Statement: Not applicable.

Informed Consent Statement: Not applicable. 
Data Availability Statement: Not applicable.

Conflicts of Interest: The authors declare no conflict of interest.

\section{References}

1. Goessling, S.; Scott, D.; Hall, C.M. Pandemics, tourism and global change: A rapid assessment of COVID-19. J. Sustain. Tour. 2020, 29, 1-20. [CrossRef]

2. Hall, C.M.; Scott, D.; Gössling, S. Pandemics, transformations and tourism: Be careful what you wish for. Tour. Geogr. 2020, 22, 577-598. [CrossRef]

3. Higgins-Desbiolles, F. Socialising tourism for social and ecological justice after COVID-19. Tour. Geogr. 2020, 22, 610-623. [CrossRef]

4. Lapointe, D. Reconnecting tourism after COVID-19: The paradox of alterity in tourism areas. Tour. Geogr. 2020, 22, 633-638. [CrossRef]

5. Nepal, S.K. Travel and tourism after COVID-19-business as usual or opportunity to reset? Tour. Geogr. 2020, 22, 646-650. [CrossRef]

6. Niewiadomski, P. COVID-19: From temporary de-globalisation to a re-discovery of tourism? Tour. Geogr. 2020, 22, 651-656. [CrossRef]

7. Sigala, M. Tourism and COVID-19: Impacts and implications for advancing and resetting industry and research. J. Bus. Res. 2020, 117, 312-321. [CrossRef]

8. Wen, J.; Wang, W.; Kozak, M.; Liu, X.; Hou, H. Many brains are better than one: The importance of interdisciplinary studies on COVID-19 in and beyond tourism. Tour. React. Res. 2020, 46, 310-313. [CrossRef]

9. Ritchie, B.W.; Mair, J.; Walters, G. Tourism crises and disasters. Wiley Blackwell Companion Tour. 2014, 49, 611-622.

10. Aldunce, P.; Beilin, R.; Handmer, J.; Howden, M. Framing disaster resilience: The implications of the diverse conceptualisations of "bouncing back". Disaster Prev. Manag. 2014, 23, 252-270. [CrossRef]

11. Folke, C. Resilience: The emergence of a perspective for social-ecological systems analyses. Glob. Environ. Chang. 2006, 16, 253-267. [CrossRef]

12. Amore, A.; Prayag, G.; Hall, C.M. Conceptualizing destination resilience from a multilevel perspective. Tour. Rev. Int. 2018, 22, 235-250. [CrossRef]

13. Holling, C.S.; Gunderson, L.H. Resilience and adaptive cycles. In Panarchy: Understanding Transformations in Human and Natural Systems; Island Press: Washington, DC, USA, 2002; pp. 25-62.

14. Holling, C.S. Resilience and stability of ecological systems. Annu. Rev. Ecol. Evol. Syst. 1973, 4, 1-23. [CrossRef]

15. Davoudi, S.; Shaw, K.; Haider, L.J.; Quinlan, A.E.; Peterson, G.D.; Wilkinson, C. Resilience: A bridging concept or a dead end? "Reframing" resilience: Challenges for planning theory and practice interacting traps: Resilience assessment of a pasture management system in Northern Afghanistan urban resilience: What does it mean in planning practice? Resilience as a useful concept for climate change adaptation? The politics of resilience for planning: A cautionary note: Edited by Simin Davoudi and Libby Porter. Plan. Theory Pract. 2012, 13, 299-333.

16. Norris, F.H.; Stevens, S.P.; Pfefferbaum, B.; Wyche, K.F.; Pfefferbaum, R.L. Community resilience as a metaphor, theory, set of capacities, and strategy for disaster readiness. Am. J. Community Psychol. 2008, 41, 127-150. [CrossRef] [PubMed]

17. Stephenson, A.; Vargo, J.; Seville, E. Measuring and comparing organisational resilience in Auckland. Aust. J. Emerg. Manag. 2010, $25,27-32$.

18. Wildavsky, A. Searching for Safety; Transaction Publishers: New Brunswick, NJ, USA, 1991.

19. Amore, A.; Hall, M.C.; Jenkins, J. They never said 'Come here and let's talk about it': Exclusion and non-decision-making in the rebuild of Christchurch, New Zealand. Local Econom. 2017, 32, 617-639. [CrossRef]

20. Gotham, K.F.; Greenberg, M. Crisis Cities: Disaster and Redevelopment in New York and New Orleans; Oxford University Press: Oxford, UK, 2014.

21. Pelling, M. The Vulnerability of Cities: Natural Disasters and Social Resilience; Earthscan: London, UK, 2003.

22. Meerow, S.; Newell, J.P.; Stults, M. Defining urban resilience: A review. Landsc. Urban Plan. 2016, 147, 38-49. [CrossRef]

23. Sharifi, A.; Yamagata, Y. Urban resilience assessment: Multiple dimensions, criteria, and indicators. In Urban Resilience; Springer: Cham, Switzerland, 2016; pp. 259-276.

24. Traskevich, A.; Fontanari, M. Tourism potentials in post-COVID19: The concept of destination resilience for advanced sustainable management in tourism. Tour. Plan. Dev. 2021, 1-25. [CrossRef]

25. Hall, C.M.; Prayag, G.; Amore, A. Tourism and Resilience: Individual, Organisational and Destination Perspectives; Channel View Publications: Bristol, UK, 2018.

26. Barrios, M.; Borrego, A.; Vilaginés, A.; Ollé, C.; Somoza, M. A bibliometric study of psychological research on tourism. Scientometrics 2008, 77, 453-467. [CrossRef]

27. Hall, C.M. Systems of surveillance and control: Commentary on 'an analysis of institutional contributors to three major academic tourism journals: 1992-2001'. Tour. Manag. 2005, 26, 653-656. [CrossRef]

28. Hall, C.M. Publish and perish? Bibliometric analysis, journal ranking and the assessment of research quality in tourism. Tour. Manag. 2011, 32, 16-27. [CrossRef] 
29. Prayag, G.; Orchiston, C.; Pennington-Grey, L. Tourism Management Perspectives Special Issue: Resilience of the Tourism and Hospitality Industry. 2018. Available online: http://media.journals.elsevier.com/content/files/79960-20054637.pdf (accessed on 2 August 2021).

30. Cochrane, J. The sphere of tourism resilience. Tour. Recreat. Res. 2010, 35, 173-185. [CrossRef]

31. Luthe, T.; Wyss, R. Assessing and planning resilience in tourism. Tour. Manag. 2014, 44, 161-163. [CrossRef]

32. Filimonau, V.; De Coteau, D. Tourism resilience in the context of integrated destination and disaster management (DM2). Int. J. Tour. Res. 2020, 22, 202-222. [CrossRef]

33. Lew, A.A.; Cheer, J.M. Tourism Resilience and Adaptation to Environmental Change: Definitions and Frameworks; Routledge: London, UK, 2017.

34. Jones, P.; Comfort, D. The Role of Resilience in Research and Planning in the Tourism Industry. Athens J. Tour. 2020, 7, 1-16. [CrossRef]

35. Cai, H.; Lam, N.S.N.; Qiang, Y.; Azou, L.; Correll, R.M.; Mihunov, V. A synthesis of disaster resilience measurement methods and indices. Int. J. Disaster Risk Reduct. 2018, 31, 844-855. [CrossRef]

36. Niezgoda, A.; Awedyk, M. Resilience planning as an opportunity for future sustainable development in tourism In Operations Research and Decisions; Wroclaw University of Technology, Institute of Organization and Management: Wrocław, Poland, 2018; Volume 2, pp. $23-40$.

37. Bangwayo-Skeete, P.F.; Skeete, R.W. Modelling tourism resilience in small island states: A tale of two countries. Tour. Geogr. 2021, 23, 436-457. [CrossRef]

38. Liu, A.; Pratt, S. Tourism's vulnerability and resilience to terrorism. Tour. Manag. 2017, 60, 404-417. [CrossRef]

39. Prideaux, B.; Laws, E.; Faulkner, B. Events in Indonesia: Exploring the limits to formal tourism trends forecasting methods in complex crisis situations. Tour. Manag. 2003, 24, 475-487. [CrossRef]

40. Roege, P.E. Creating Value Through Resilience. In IRGC Resource Guide on Resilience; Florin, M.V., Linkov, I., Eds.; EPFL International Risk Governance Center: Lausanne, Switzerland, 2016.

41. Cellini, R.; Cuccia, T. The economic resilience of tourism industry in Italy: What the great recession data show. Tour. Manag. Perspect. 2015, 16, 346-356. [CrossRef]

42. Dai, S.; Xu, H.; Chen, F. A hierarchical measurement model of perceived resilience of urban tourism destination. Soc. Indic. Res. 2019, 145, 777-804. [CrossRef]

43. Lew, A.A.; Ng, P.T.; Ni, C.C.; Wu, T.C. Community sustainability and resilience: Similarities, differences and indicators. Tour. Geogr. 2016, 18, 18-27. [CrossRef]

44. D'Hauteserre, A.M. Lessons in managed destination competitiveness: The case of Foxwoods Casino Resort. Tour. Manag. 2000, 21, 23-32. [CrossRef]

45. Schnitzer, M.; Seidl, M.; Schlemmer, P.; Peters, M. Analyzing the Coopetition between Tourism and Leisure Suppliers-A Case Study of the Leisure Card Tirol. Sustainability 2018, 10, 1447. [CrossRef]

46. Orchiston, C.; Prayag, G.; Brown, C. Organizational resilience in the tourism sector. Ann. Tour. Res. 2016, 56, 145-148. [CrossRef]

47. Paraskevas, A.; Altinay, L.; Mclean, J.; Cooper, C. Crisis knowledge in tourism: Types, flows and governance. Ann. Tour. Res. 2013, 41, 130-152. [CrossRef]

48. Prayag, G.; Spector, S.; Orchiston, C.; Chowshury, M. Psychological resilience, organizational resilience and life satisfaction in tourismfi firms: Insight from the Canterbury earthquakes. Curr. Issues Tour. 2020, 23, 1216-1233. [CrossRef]

49. Chesbrough, H. Open innovation a new paradigm for understanding industrial innovation. In Researching a New Paradigm; Oxford University Press: Oxford, UK, 2006; Volume 400, pp. 1-19.

50. Della, C.V.; Aria, M.; Del Gaudio, G. Smart, open, user innovation and competitive advantage: A model for museums and heritage sites. Mus. Manag. Curator. 2017, 32, 50-79. [CrossRef]

51. Gretzel, U.; Scarpino-Johns, M. Destination resilience and smart tourism destinations. Tour. Rev. Int. 2018, 22, 263-276. [CrossRef]

52. Hartman, S. Resilient tourism destinations? Governance implications of bringing theories of resilience and adaptive capacity to tourism practice. In Destination Resilience: Challenges and Opportunities for Destination Management and Governance; Innerhofer, E., Fontanari, M., Pechlaner, H., Eds.; Routledge: London, UK, 2018; pp. 66-76.

53. Schroeder, A.; Pennington-Gray, L.; Donohoe, H.; Kiousis, S. Using social media in times of crisis. J. Travel Tour. Mark. 2013, 30, 126-143. [CrossRef]

54. Donthu, N.; Kumar, S.; Mukherjee, D.; Pandey, N.; Lim, W.M. How to conduct a bibliometric analysis: An overview and guidelines. J. Bus. Res. 2021, 133, 285-296. [CrossRef]

55. Aznar-Sánchez, J.A.; Velasco-Muñoz, J.F.; Belmonte-Ureña, L.J.; Manzano-Agugliaro, F. The worldwide research trends on water ecosystem services. Ecol. Indic. 2019, 99, 310-323. [CrossRef]

56. Carrión-Mero, P.; Montalván-Burbano, N.; Morante-Carballo, F.; Quesada-Román, A.; Apolo-Masache, B. Worldwide research trends in landslide science. Int. J. Environ. Res. Public Health 2021, 18, 9445. [CrossRef]

57. Hallinger, P.; Kovačević, J. Science mapping the knowledge base in educational leadership and management: A longitudinal bibliometric analysis, 1960 to 2018. Educ. Manag. Adm. Leadersh. 2021, 49, 5-30. [CrossRef]

58. Jiang, Y.; Ritchie, B.W.; Benckendorff, P. Bibliometric visualisation: An application in tourism crisis and disaster management research. Curr. Issues Tour. 2019, 22, 1925-1957. [CrossRef] 
59. Hall, C.M. Resilience in Tourism: Development, Theory, and Application in Tourism, Resilience and Sustainability; Routledge: London, UK, 2017.

60. Warin, T. Global Research on Coronaviruses: An R Package. J. Med. Internet Res. 2020, 22, e19615. [CrossRef] [PubMed]

61. Aria, M.; Cuccurullo, C. Bibliometrix: An R-tool for comprehensive science mapping analysis. J. Infometr. 2017, 11, 959-975. [CrossRef]

62. Derviş, H. Bibliometric Analysis using Bibliometrix an R Package. J. Scientometr. Res. 2019, 8, 156-160. [CrossRef]

63. Jasmin, R.J.; Biju, A.V.; Akhil, M.P. Research Collaboration and Networking in Mergers and Acquisitions-An Analysis of Citation and Co-Author Networks using Bibliometrix Package. Int. J. Manag. 2020, 11, 1383-1391.

64. Almeida, F.; de Paula, L.G. The Place of Uncertainty in Heterodox Economics Journals: A Bibliometric Study. J. Econom. Issues 2019, 53, 553-562. [CrossRef]

65. Campra, M.; Esposito, P.; Brescia, V. State of the art of COVID-19 and business, management and accounting sector. A biliometrix analysis. Int. Bus. Manag. 2020, 16, 35. [CrossRef]

66. Bretas Vanessa, P.G.; Alon, I. Franchising research on emerging markets: Bibliometric and content analyses. J. Bus. Res. 2021, 133, 51-65. [CrossRef]

67. Palacios, H.; de Almeida, M.H.; Sousa, M.J. A bibliometric analysis of trust in the field of hospitality and tourism. Int. J. Hosp. Manag. 2021, 95, 102944. [CrossRef]

68. Kırtıl, İ.G.; Aşkun, V. Artificial Intelligence in Tourism: A Review and Bibliometrics Research. Adv. Hosp. Tour. Res. (AHTR) 2021, 9, 205-233.

69. Kim, Y.R.; Liu, A.; Williams, A.M. Competitiveness in the visitor economy: A systematic literature review. Tour. Econom. 2021. [CrossRef]

70. Quesado, P.; Silva, R. Activity-Based Costing (ABC) and Its Implication for Open Innovation. J. Open Innov. Technol. Mark. Complex. 2021, 7, 41. [CrossRef]

71. Demiroz, F.; Haase, T.W. The concept of resilience: A bibliometric analysis of the emergency and disaster management literature. Local Gov. Stud. 2019, 45, 308-327. [CrossRef]

72. Medie, P.A.; Kang, A.J. Power, knowledge and the politics of gender in the Global South. J. Politics Gend. (EJPG) 2018, 1, 37-53 [CrossRef]

73. Akintunde, T.Y.; Musa, T.H.; Musa, H.H.; Musa, I.H.; Chen, S.; Ibrahim, E.; Tassang, A.E.; Helmy, M. Bibliometric analysis of global scientific literature on effects of COVID-19 pandemic on mental health. J. Psychiatry 2021, 63, 102753. [CrossRef]

74. Hudson, R. Resilient regions in an uncertain world: Wishful thinking or practical reality? Camb. J. Reg. Econ. Soc. 2010, 3, 11-25. [CrossRef]

75. Fabry, N.; Zeghni, S. Resilience, tourist destinations and governance: An analytical framework. In Tourismes et Adaptations; Cholat, F., Gwiazdzinski, L., Tritz, C., Eds.; Elya: Grenoble, France, 2019; pp. 96-108.

76. Morrish, S.C.; Jones, R. Post-disaster business recovery: An entrepreneurial marketing perspective. J. Bus. Res. 2020, 113, 83-92. [CrossRef]

77. Gong, R.; Xue, J.; Zhao, L.; Zolotova, O.; Ji, X.; Xu, Y. A Bibliometric Analysis of Green Supply Chain Management Based on the Web of Science (WOS) Platform. Sustainability 2019, 11, 3459. [CrossRef]

78. Zhu, J.; Liu, W.A. Tale of Two Databases: The Use of Web of Science and Scopus in Academic Papers. Scientometrics 2020, 123, 321-335. [CrossRef]

79. Li, K.; Rollins, J.; Yan, E. Web of Science use in published research and review papers 1997-2017 A selective, dynamic, crossdomain, content-based analysis. Scientometrics 2018, 115, 1-20. [CrossRef] [PubMed]

80. Archambault, E.; Vignola-Gagne, E.; Coté, G.; Larivière, V.; Gingras, Y. Benchmarking scientific output in the social sciences and humanities: The limits of existing databases. Scientometrics 2006, 68, 329-342. [CrossRef]

81. Chavarro, D.; Ràfols, I.; Tang, P. To what extent is inclusion in the Web of Science an indicator of journal 'quality'? Res. Eval. 2018, 27, 106-118. [CrossRef]

82. Echchakoui, S. Why and how to merge Scopus and Web of Science during bibliometric analysis: The case of sales force literature from 1912 to 2019. J. Market. Anal. 2020, 8, 165-184. [CrossRef]

83. Pranckute, R. Web of Science (WoS) and Scopus: The Titans of Bibliographic Information in Today's Academic World. Publications 2021, 9, 12. [CrossRef]

84. Stockemer, D.; Wigginton, M.J. Publishing in English or another language: An inclusive study of scholar's language publication preferences in the natural, social and interdisciplinary sciences. Scientometrics 2019, 118, 645-652. [CrossRef]

85. López-Navarro, I.; Moreno, A.I.; Quintanilla, M.Á.; Rey-Rocha, J. Why do I publish research articles in English instead of my own language? Differences in Spanish researchers' motivations across scientific domains. Scientometrics 2015, 103, 939-976. [CrossRef]

86. Majerova, I.; Abdrazakova, A. A Bibliometric Mapping of Cost-Benefit Analysis-Three Decades of Studies. Econom. Open Access J. 2021, 9, 110. [CrossRef]

87. Noyons, E.C.M.; Moed, H.F.; Van Raan, A.F.J. Integrating research performance analysis and science mapping. Scientometric 1999, 46, 591-604. [CrossRef]

88. Hu, H.; Qiao, X.; Yang, Y.; Zhang, L. Developing a resilience evaluation index for cultural heritage site: Case study of Jiangwan Town in China. Asia Pac. J. Tour. Res. 2021, 26, 15-29. [CrossRef] 
89. Barbhuiya, M.R.; Chatterjee, D. Vulnerability and resilience of the tourism sector in India: Effects of natural disasters and internal conflict. Tour. Manag. Perspect. 2020, 33, 100616. [CrossRef]

90. Egger, R.; Gula, I.; Walcher, D. Open Tourism; Springer: New York, NY, USA, 2016.

91. Nordin, S.; Svensson, B. Innovative Destination Governance: The Swedish Ski Resort of Åre. Int. J. Entrep. Innov. 2007, 8, 53-66. [CrossRef]

92. Zach, F. Partners and innovation in American destination marketing organizations. J. Travel Res. 2012, 51, 412-425. [CrossRef]

93. Ali, A.; Frew, A.J. Technology innovation and applications in sustainable destination development. Inf. Technol. Tourism 2014, 14, 265-290. [CrossRef]

94. Paulino, I.; Lozano, S.; Prats, L. Identifying tourism destinations from tourists' travel patterns. J. Destin. Mark. Manag. 2021, 19, 100508. [CrossRef]

95. Dredge, D. Policy networks and the local organisation of tourism. Tour. Manag. 2006, 27, 269-280.

96. Hjalager, A.M. Repairing innovation defectiveness in tourism. Tour. Manag. 2002, 23, 465-474. [CrossRef]

97. Borseková, K.; Vaňová, A.; Vitálišová, K. Smart Specialization for Smart Spatial Development: Innovative Strategies for Building Competitive Advantages in Tourism in Slovakia. Socio-Econ. Plan. Sci. 2017, 58, 39-50. [CrossRef]

98. Krozer, Y.; Christensen-Redzepovic, E. Sustainable Innovations at Tourist Destinations. Tour. Rev. Int. 2006, 10, 113-124. [CrossRef]

99. Triantafillidou, E.; Tsiaras, S. Exploring entrepreneurship, innovation and tourism development from a sustainable perspective: Evidence from Greece. J. Int. Bus. Entrep. Dev. (JIBED) 2018, 11, 1. [CrossRef]

100. Seraphin, H.; Gowreesunkar, V.G.B. Conclusion-tourism: How to achieve the sustainable development goals? Worldw. Hosp. Tour. Themes 2021, 1, 148-152. [CrossRef]

101. Paskaleva, K.; Cooper, I.; Azorin, J.A. Soft factors in integrating innovation in advanced e-services. Int. J. Serv. Technol. Manag. (IJSTM) 2011, 15, 3-4. [CrossRef]

102. Scuttari, A.; Della Lucia, M.; Martini, U. Integrated planning for sustainable tourism and mobility. A tourism traffic analysis in Italy's South Tyrol region. J. Sustain. Tour. 2013, 21, 614-637. [CrossRef]

103. Calgaro, E.; Lloyd, K.; Dominey-Howes, D. From vulnerability to transformation: A framework for assessing the vulnerability and resilience of tourism destinations. J. Sustain. Tour. 2014, 22, 341-360. [CrossRef]

104. De Uña-Álvarez, E.; Villarino-Pérez, M. Adaptive strategies for inland touristic destinations (sil canyon, galicia, nw spain). Cuad. Tur. 2017, 40, 203-224. [CrossRef]

105. Beirman, D.; Upadhayaya, P.K.; Pradhananga, P.; Darcy, S. Nepal tourism in the aftermath of the April/May 2015 earthquake and aftershocks: Repercussions, recovery and the rise of new tourism sectors. Tour. Recreat. Res. 2018, 43, 544-554. [CrossRef]

106. Cave, J.; Dredge, D. Regenerative tourism needs diverse economic practices. Tour. Geogr. 2020, 22, 503-513. [CrossRef]

107. Türkcan, K.; Erkuş-Öztürk, H. The impact of economic and political crises on the survival of tourism-related firms: Evidence from Antalya. Tour. Econ. 2020, 26, 1152-1174. [CrossRef]

108. Student, J.; Kramer, M.R.; Steinmann, P. Simulating emerging coastal tourism vulnerabilities: An agent-based modelling approach. Ann. Tour. Res. 2020, 85, 103034. [CrossRef]

109. Choi, J.; Lee, S.; Jamal, T. Smart Korea: Governance for smart justice during a global pandemic. J. Sustain. Tour. 2021, 29, 541-550. [CrossRef]

110. Dias, Á.L.; Silva, R.; Patuleia, M.; Estêvão, J.; González-Rodríguez, M.R. Selecting lifestyle entrepreneurship recovery strategies: A response to the COVID-19 pandemic. Tour. Hosp. Res. 2021. [CrossRef]

111. Demiroglu, O.C.; Kučerová, J.; Ozcelebi, O. Snow reliability and climate elasticity: Case of a Slovak ski resort. Tour. Rev. 2015, 70, 1-12. [CrossRef]

112. Coles, T.; Dinan, C.; Warren, N. Climate change mitigation and the age of tourism accommodation buildings: A UK perspective. J. Sustain. Tour. 2015, 23, 900-921. [CrossRef]

113. Scott, D.; Hall, C.M.; Gössling, S. A report on the Paris Climate Change Agreement and its implications for tourism: Why we will always have Paris. J. Sustain. Tour. 2016, 24, 933-948. [CrossRef]

114. Veiga, C.; Santos, M.C.; Águas, P.; Santos, J.A.C. Sustainability as a key driver to address challenges. Worldv. Hosp. Tour. Themes 2018, 10, 662-673. [CrossRef]

115. Moreno-Izquierdo, L.; Ramón-Rodriguez, A.; Such-Devesa, M.J. The challenge of long-term tourism competitiveness in the age of innovation: Spain as a case study. Investig. Reg. 2018, 32, 42.

116. Nilsson, J.H. Conceptualizing and contextualizing overtourism: The dynamics of accelerating urban tourism. Int. J. Tour. Cities 2020, 6, 657-671. [CrossRef]

117. Ganzaroli, A.; De Noni, I.; Bonera, M. The influence of foreigners' buzzing on TripAdvisor ranking of restaurants in Venice: Implications for the sustainability of over-touristed heritage cities. Curr. Issues Tour. 2021, 24, 2044-2058. [CrossRef]

118. Gretzel, U.; Sigala, M.; Xiang, Z.; Koo, C. Smart tourism: Foundations and developments. Electron. Mark. 2015, 25, 179-188. [CrossRef]

119. Hirsch, J.E. An index to quantify an individual's scientific research output. Proc. Natl. Acad. Sci. USA 2005, 102, 16569-16572. [CrossRef]

120. Della Corte, V.; Del Gaudio, G.; Sepe, F.; Sciarelli, F. Sustainable tourism in the open innovation realm: A bibliometric analysis. Sustainability 2019, 11, 6114. [CrossRef] 
121. Cobo, M.J.; López-Herrera, A.G.; Herrera-Viedma, E.; Herrera, F. Science mapping software tools: Review, analysis, and cooperative study among tools. J. Assoc. Inf. Sci. Technol. 2011, 62, 1382-1402. [CrossRef]

122. Cahlik, T. Comparison of the maps of science. Scientometrics 2000, 49, 373-387. [CrossRef]

123. Gursoy, D.; Chi, O.H.; Lu, L.; Nunkoo, R. Consumers acceptance of artificially intelligent (AI) device use in service delivery. Int. J. Inf. Manag. 2019, 49, 157-169. [CrossRef]

124. Lin, H.; Chi, O.H.; Gursoy, D. Antecedents of customers' acceptance of artificially intelligent robotic device use in hospitality services. J. Hosp. Mark. Manag. 2020, 29, 530-549. [CrossRef]

125. Gursoy, D.; Chi, C.G. Effects of COVID-19 pandemic on hospitality industry: Review of the current situations and a research agenda. J. Hosp. Mark. Manag. 2020, 29, 527-529. [CrossRef]

126. Gretzel, U.; Fuchs, M.; Baggio, R.; Hoepken, W.; Law, R.; Neidhardt, J. e-Tourism beyond COVID-19: A call for transformative research. Inf. Technol. Tourism 2020, 22, 187-203. [CrossRef]

127. Mukherji, N.; Silberman, J. Absorptive capacity, knowledge flows, and innovation in u.s. metropolitan areas. J. Reg. Sci. 2013, 53, 392-417. [CrossRef]

128. Ponce-Espinosa, G.; Peiro-Signes, A.; Segarra-Oña, M. Absorptive capacity and in-company routines: Modelling knowledge creation in the tourism industry. Knowl. Manag. Res. Pract. 2020, 1, 1-11. [CrossRef]

129. Wilke, E.P.; Costa, B.K.; Freire, O.B.D.L.; Ferreira, M.P. Interorganizational cooperation in tourist destination: Building performance in the hotel industry. Tour. Manag. 2019, 72, 340-351. [CrossRef]

130. Brandão, F.; Breda, Z.; Costa, C. Innovation and internationalization as development strategies for coastal tourism destinations: The role of organizational networks. J. Hosp. Tour. Manag. 2019, 41, 219-230. [CrossRef]

131. Chang, Y.W.; Li, T.C.; Chen, Y.C.; Lee, J.H.; Chang, M.C.; Huang, L.C. Exploring Knowledge and Experience of Health Literacy for Chinese-Speaking Nurses in Taiwan: A Cross-Sectional Study. Int. J. Environ. Res. Public Health 2020, 17, 7609. [CrossRef]

132. Prideaux, B.; Thompson, M.; Pabel, A. Lessons from COVID-19 can prepare global tourism for the economic transformation needed to combat climate change. Tour. Geogr. 2020, 22, 667-678. [CrossRef]

133. Benjamin, S.; Dillette, A.; Alderman, D.H. We can't return to normal: Committing to tourism equity in the post-pandemic age. Tour. Geogr. 2020, 22, 476-483. [CrossRef]

134. Stankov, U.; Filimonau, V.; Vujičić, M.D. A mindful shift: An opportunity for mindfulness-driven tourism in a post-pandemic world. Tour. Geogr. 2020, 22, 703-712. [CrossRef]

135. Sharma, G.D.; Thomas, A.; Paul, J. Reviving tourism industry post-COVID-19: A resilience-based framework. Tour. Manag. Perspect. 2021, 37, 100786. [CrossRef]

136. Galvani, A.; Lew, A.A.; Perez, M.S. COVID-19 is expanding global consciousness and the sustainability of travel and tourism. Tour. Geogr. 2020, 22, 567-576. [CrossRef]

137. Whybark, D.C. Co-creation of improved quality in disaster response and recovery. Int. J. Qual. Innov. 2015, 1, 3. [CrossRef]

138. De Sausmarez, N. Crisis Management, Tourism and Sustainability: The Role of Indicators. J. Sustain. Tour. 2007, 15, 700-714. [CrossRef]

139. Poor, P.J.; Smith, J.M. Travel cost analysis of a cultural heritage site: The case of historic St Mary's City of Maryland. J. Cult. Econ. 2004, 28, 217-229. [CrossRef]

140. Calgaro, E.; Lloyd, K. Sun, sea, sand and tsunami: Examining disaster vulnerability in the tourism community of Khao Lak, Thailand. Singap. J. Trop. Geogr. 2008, 29, 288-306. [CrossRef]

141. Farrell, B.H.; Twining-ward, L. Reconceptualising tourism. Ann. Tour. Res. 2004, 31, 274-295. [CrossRef]

142. Lam, L.; Nguyen, P.; Le, N.; Tran, K. The Relation among Organizational Culture, Knowledge Management, and Innovation Capability: Its Implication for Open Innovation. J. Open Innov. Technol. Mark. Complex. 2021, 7, 66. [CrossRef]

143. Gretzel, U.; Reino, S.; Kopera, S.; Koo, C. Smart tourism challenges. J. Tour. 2015, 16, 41-47.

144. Yun, J.J.; Won, D.; Park, K. Dynamics from open innovation to evolutionary change. J. Open Innov. Technol. Mark. Complex. 2016, 2, 7. [CrossRef]

145. Lindroth, K.; Ritalahti, J.; Soisalon-Soininen, T. Creative tourism in destination development. Tour. Rev. 2007, 62, 53-58. [CrossRef]

146. Sharpley, R. The tsunami and tourism: A comment. Curr. Issues Tour. 2005, 8, 344-349. [CrossRef]

147. Carlsen, J.C.; Liburd, J.J. Developing a research agenda for tourism crisis management, market recovery and communications. J. Travel Tour. Mark. 2008, 23, 265-276. [CrossRef] 